\title{
The Role of Interpersonal Problem Solving in Using the Immature Defense Mechanisms in Adolescents*
}

\section{El papel desarollado por la resolución de problemas interpersonales en el uso de mecanismos de defensa inmaduros en adolescentes}

\author{
Ahmet Bedel ${ }^{\mathrm{a}}$ \\ Maltepe University, Turquía \\ ORCID: http://orcid.org/0000-0003-4215-9290
}

a Correspondence author. E-mail: ahmetbedel@maltepe.edu.tr

How to cite: Bedel, A. (2019). The role of interpersonal problem solving in using the immature defense mechanisms in adolescents. Universitas Psychologica, 18(5), 1-12. https://doi.org/10.11144/Javeriana.upsy 18-5.rips

\begin{abstract}
The purpose of this study was to examine associations between interpersonal problem solving and immature defense mechanisms in addition to whether interpersonal problem solving are predictors of immature defense mechanisms. The participants of the study consists of 428 high schools students (184 of the students were females). Interpersonal Problem Solving Inventory and Defense Style Questionnaire were applied. Results of multiple regression analyses indicated that all variables of interpersonal problem solving skills together accounted for $32 \%$ of the variance in defense mechanisms. Specifically, significant predictors of immature defense mechanisms levels were lack of self-confidence, negative approach to the problems, constructive problem solving respectively. Generally, the levels of adolescents resort to immature defense mechanisms, lack of self-confidence and negative approach to the problem of the increase, a decrease in constructive problem-solving skills are seen to be effective. The results of the study was discussd within the results of the previous studies.

Keywords

Adolescent; interpersonal problem; problem-solving approaches; lack of selfconfidence; defense mechanisms.
\end{abstract}

\section{RESUMEN}

El objetivo de este estudio fue examinar las asociaciones entre la resolución de problemas interpersonales y los mecanismos de defensa inmaduros, y averiguar si los primeros son predictores de los segundos. Los participantes fueron 428 estudiantes de enseñanza secundaria (184 mujeres). Se aplicó el Cuestionario Interpersonal de Resolución de Problemas y Tipo de Defensa. Los resultados de los análisis de regresión múltiple mostraron que la totalidad de las variables de habilidades interpersonales para resolver problemas representaban el $32 \%$ de la varianza de los mecanismos de defensa. Específicamente, los indicadores significativos de los niveles de mecanismos de defensa inmaduros fueron la falta de confianza en sí mismo, el enfoque negativo de los problemas y la resolución constructiva de problemas, respectivamente. En general, se comprobó que el nivel de mecanismos de defensa inmaduros de los adolescentes tiene un impacto negativo en el planteamiento de problemas en el aumento o en diminución de sus habilidades constructivas de 
resolución de problemas. Los resultados del estudio se discuten en el contexto de los resultados de estudios previos.

Palabras clave

adolescente; problema interpersonal; enfoques de resolución de problemas; falta de autoconfianza; mecanismos de defensa.

Adolescence period, in which development is fast, witnesses distinctive stressful and worrisome life events. Seek for independence, romantic relationships, academic achievement, professional orientation, peer relations and parental problems are important stressful life events observed in this period (Kulaksizoğlu, 2017; Santrock, 2014). Social problem solving skill, which is an approach of conscious coping with stress and worrisome life events vary across individuals (Öğ̈̈lmüş, 2006; Türnüklü, 2017). The concept of social problem solving was defined by D'Zurilla and Nezu (1971) as the application of cognitive behavioral method by individual in effectively coping with the problematic situation in daily life. There are two sub-dimensions of problem solving approach, in the social problem solving model developed by D'Zurilla and Goldfried (1971) for interpersonal problem solving. These are approach to the problem and problem solving skills. The subdimension of approach to the problem is explained with two components as positive and negative approach. Positive approach is based on positive thinking. Those people who approach to the problem positively regard the problem as a natural part of life, and have a positive opinion and feel confident on that the problem can be solved. They believe that time and effort are necessary to solve a problem successfully (D'Zurilla, Chang, \& Sanna, 2003; Eskin, 2018). That they feel competent in solving the problem makes positive contribution to their problem-solving skills (Korkut, 2017; Yenice, 2012). Some studies revealed that having problem solving skill has an effect on decrease in aggression, anger, hostility (Seçer \& Ogelman, 2011) and in negative behaviors (Bushman $\&$ Peacock, 2010), and on increase in social self-efficacy (Erözkan, 2013), positive emotion
(D'Zurilla, Maydeu-Olivares, \& Pujol, 2011) and interpersonal relationships (Joseph \& Strain, 2010; Sumi, 2012). Negative thinking is referred to as negative approach to the problem. Negative approach to the problem is the nonfunctional point of view for the problems experienced. It was concluded that individuals who have a negative point of view for the problems they face, perceive problems as a threat, and believe that these problems can't be solved, and that they will fail in solving them (D'Zurilla, Nezu, \& MaydeuOlivares, 2004), which affects their daily life adjustments negatively (Bell \& D'Zurilla, 2009) and which become effective on their spiritual signs (Ergin \& Dağ, 2013). Problem-solving skills are classified as logical, impulsive-careless, and avoiding styles, in the dimension of problem-solving skill. Logical - rational problem solving skill is referred to as constructive problem solving skill (Eskin, 2018). Impulsivecareless, and avoiding problem solving styles are nonfunctional approaches. These approaches include nonfunctional coping behaviors in solving problem, such as thoughtless, careless, avoiding the problem rather than coping it (D'Zurilla et al., 2004) and social anxiety (Baltaci $\&$ Hamarta, 2013). The purpose of the social problem solving model is to gain functional coping skill to individuals by increasing their positive approaches to the problems they face, and decreasing their negative approaches and, avoidant and careless problem solving skills (Nezu, D'Zurilla, \& Nezu, 2012). The findings of the subject suggested that individuals with negative thoughts and nonfunctional ways of coping with problems suffered from psychological distress such as more stress (Basut, 2006; Hirsch, Chang, \& Jeglic, 2012), depression (Anderson, Goddard, \& Powell, 2011; Eskin, 2018; Özdemir, Kuzucu, \& Koruklu,2013), anxiety (Karataş, 2011; Siu \& Shek, 2010) and suicidal ideation (Fidan, Ceyhun, \& Kirpinar, 2009; Holen, Lervag, Waaktaar, \& Ystgaard, 2012; Spirito, Francis, Overholser, \& Frank, 1996). While social problem solving skill is one of the ways of conscious coping with stress and anxious in life, defense mechanisms are defined as unconscious way of coping with those (Cüceloğlu, 2018, 
p. 301). Defense is the basic mechanism of personality, and mental health workers attempt to influence this situation through consultation (Perry \& Metzger, 2014). When used within certain limits, defense mechanisms help people in difficult situations until they manage to cope with stressful situations more directly (Cramer, 1998). With the help of defense mechanisms, the adjustment between id, superego and environmental forces is balanced, contributing to ego to gain strength (Freud, 2015, p. 105). While defense mechanisms provide temporary relief, they often distort reality, and prevent problems from being solved effectively. A person who is bound up with defense mechanisms may never learn more effective ways to cope with problems (Cüceloğlu, 2018). The ego defense mechanisms in adolescence period aims at to protect the psychological integrity and balance of the organism. Everybody uses various defense mechanisms to sustain his/her psychological integrity and to preserve the value of his/her own ego. If these reactions become a main tool to cope with constrained situations, and are exaggerated so that they will prevent individual's adjustment, then they will become unhealthy (Cüceloğlu, 2018; Geçtan, 2017). The energy spent to plead reduces the energy available for a productive and satisfying life (Gerring \& Zimbardo, 2016). In the study conducted by Andrews, Singh, and Bond (1993); (Yllmaz, Gençöz, \& Ak, 2007), defense mechanisms were collected under three headings, including mature defenses (sublimation, humor, expectation, suppression), immature defenses (reflection, passive aggression, externalise, derogation, denial, displacement, splitting, rationalization, somatization), and neurotic defenses (make - disrupt, idealization, reaction formation, altruism). Mature defense mechanism is considered as a functional defense form. The findings of the relevant studies suggested that healthy individuals use mature defense mechanisms more frequently, and exhibit compatible behaviors (Yllmaz et al., 2007). Mature defense mechanisms allow undesirable emotions to be expressed in socially acceptable forms (Pellitteri, 2002) and to reduce the difficulties experienced (Hentschel, Smith, \& Draguns, 2004). While those people who have confident personality trait use mature defense mechanisms such as humor and sublimation, those people who have antisocial personality trait use immature defense mechanisms such as denial (Weinberger, 1998). These mature defense mechanisms contribute to attain new meanings and perspectives in conflict resolution (Metzger, 2014). In the study conducted by Evren et al. (2012), it was determined that alcohol users using mature defense mechanism exhibit less self-harm behaviors. The use of mature defense mechanism was found to have an important relationship with negative attitude against empathy, competence and hostility (Davidson, MacGregor, Johnson, Woody, \& Chaplin, 2004), with low depressive symptoms (Waqas et al., 2015), social skills and mature behaviors (Cramer, 2002; Kwon, 2002), with positive perfectionism (Dickinson \& Ashby, 2005; Flett, Besser, \& Hewitt, 2005), with life satisfaction (Lyke, 2016). On the other hand, individuals using immature and neurotic defense mechanisms are seen to show negative symptoms of mental health. The use of immature and neurotic defense mechanism was found to have a significant relationship with stress (Hyphantis, Palieraki, Voulgari, Tsifetaki, \& Drosos, 2011), negative emotions (Steiner et al., 2007), somatic complaints (Hyphantis, Goulia, \& Carvalho, 2013), avoidant personal trait (Seaton \& Beaumont, 2011), antisocial personality trait (Presniak, Olson, \& Macgregor, 2010), mood disorder, panic disorder (ChávezLeón, Lara-Muñoz, \& Ontiveros-Uribe, 2006), personality disorder (Cramer, 1999), alcohol (Brody \& Costa, 2013) and anger (Offer, Lavie, Gothelf, \& Apter, 2000). In the studies of which physical health related outcomes, as well as mental health related outcomes, were discussed, it was found that those people with mature defense mechanisms have better physical health in advanced life (Malone, Cohen, Liu, Vaillant, \& Waldinger, 2013).

The above explanations show that there are relationships between defense mechanisms and various social, psychological and emotional 
variables. In the literature review, any study investigating the relationship between problem solving skills and defense mechanisms in domestic and abroad people hasn't been found. It is believed that the outcomes of this study will provide important contributions to the problem solving and defense mechanisms literature. This research was conducted on high school students. The biological, cognitive and social changes that are experienced in this period can also lead to emotional tension. There may also be an increase in students' interpersonal problems with family and surroundings. Students' problem solving approaches towards the problems they faced, conscious coping skills, and unconscious coping approaches are within psychological counselors' field of interest. Accordingly, it is expected that the findings of this research will guide to the formation of the contents of preventive guidance and psychological counseling programs to be prepared by psychological counselors working in schools. In this context, the purpose of the study is to investigate the relationships between interpersonal problem-solving approaches and immature defense mechanisms, and to determine whether immature defense mechanisms can be significantly predicted through interpersonal problem-solving approaches.

\section{Method}

\section{Participants}

The study was conducted in accordance with overall screening model. The universe of the study consisted of high school students in Konya province center. The sample of the study consisted of 15 classes, randomly selected from the classes with an average of 30 students in each, determined by the simple random sampling method from the classes in vocational high school and the anatolian high school in the central district, of which students were thought to represent the high school students in general. The scales used in the study were applied to a total of 450 students in these classes, and the test batteries of 22 students who didn't fully fill out the items in the scales were excluded from the assessment. The average age of the students participating in the study was 17.24 (SD:1.04). The other demographic characteristics of the sample are shown in Table 1 .

\section{Table 1}

Gender, class and school type information of participants

\begin{tabular}{clcc}
\hline & Variables & Frequency & Percent \\
\hline \multirow{3}{*}{ Gender } & Female & 184 & 44 \\
& Male & 244 & 56 \\
& Total & 428 & 100 \\
\hline \multirow{3}{*}{ Class } & 11. Class & 242 & 56 \\
& 12. Class & 186 & 44 \\
& Total & 428 & 100 \\
\hline \multirow{3}{*}{ School Type } & Vocational High School & 338 & 78 \\
& Anatolian High School & 90 & 22 \\
& Total & 428 & 100 \\
\hline
\end{tabular}

\section{Instruments}

Interpersonal Problem Solving Inventory ([IPSI]; Çam Ë Tümkaya, 2008)

IPSI is a 5 point Likert scale $(1=$ Not suitable at all, $5=$ Completely suitable) consisting of 50 items, developed to measure the problemsolving approaches and skills of high school students. The scale consists of a total of five subscales, including negative approach tothe problem (NAP), constructive problem solving (CPS), lack of self-confidence (LS), unwilling to take responsibility (UR), insistent-persevering approaches (I-PA). The high score obtained from each subscale indicates that the relevant feature of interpersonal problem-solving is high. The internal consistency Cronbach's alpha coefficients of subscale scores of IPSI were found as follows: $\mathrm{NAP}=0.89, \mathrm{CPS}=0.87, \mathrm{LS}=0.67$, $\mathrm{UR}=0.68$ and I-PA $=0.7$. The test-retest correlation values of the inventory was found to range between .67 and .84 (Çam \& Tümkaya, 2008). In the scope of this study, the internal consistency Cronbach's alpha coefficients of subscale scores of IPSI were found as follows: $\mathrm{NAP}=0.86, \mathrm{CPS}=0.83, \mathrm{LS}=0.67, \mathrm{UR}=0.73$ and I-PA $=0.76$ 
Defense Style Questionnaire (DSQ, 1999).

The questionnaire which measures ego defenses was developed by Bond, Gardner, Christian and Sigal in 1983 (cited in Bodur, 1999). The short form of the questionnaire was obtained as a result of its adaptation to Turkish, performed by Bodur (1999). DSQ is a 9 point likert scale $(1=$ Not suitable for me at all, $5=$ Completely suitable for me) consisting of 26 items, developed to measure the defense ways of individuals aged 19 years and over. The high total score obtained indicates that the level of immature defense is high. In the reliability study, DSQ short form was found to have high internal consistency $(\alpha$ $=0.71)$. In the validity study, it was seen that DSQ short form had significant relationships with continuous anxiety scale (Öner, 1977) $r$ $=0.38, p<0.05$, with social comparison scale (Savaşır \& Şahin, 1997) $r=-0.41, p<0.05$, with neuroticism $r=0.72, p<0.001$, and psychotism dimensions of Eysenk Personality Test (Öner, 1977). Based on these results, it is thought that the DSQ short form can evaluate immature ego defense mechanisms more accurately (Bodur, 1999). Besides, due to the fact that reliability and validity studies during the Turkish adaptation of the scale was conducted on individuals aged 19 years and over, and that the mean age was 17.24 in the study, the validity of the reliability studies were conducted to determine the appropriateness of the scale to the relevant age group. Within the scope of this study, the Cronbach's alpha coefficient of the scale was found as .88 . The scale was found very compatible $\left(\chi^{2} / d f=1.89, \mathrm{GFI}=0.9, \mathrm{CFI}=\right.$ 0.91 , RMSEA $=0.051$, SRMR $=0.054)$ with the sampling data, as a result of confirmatory factor analysis made.

\section{Procedure}

The scales used in the study were applied by the school counselor to the students within the class hours. Before the application, the purpose of the study was briefly explained to the students, and only volunteers were provided to participate in the study, by receiving the approval of the students. The data were also evaluated for the compatibility with multiple analyzes; skewness and kurtosis coefficients were found to range between -0.39 and 0.34 and -0.74 and -0.2 , respectively, for each variable used in the study, and, it was observed that they satisfied the assumption of normal distribution since the data range between +1 and -1 (Tabachnik \& Fidel, 2015).

\section{Data analysis}

In order to examine potential relations among research variables which are interpersonal problem solving, and immature defense style scores, Pearson Moments Multiplication Correlation coefficients have been calculated. To the end of determining explanatory ratio of interpersonal problem solving on immature defense mechanisms Multiple Regression Analysis has been employed. Their relative explanatory levels have been compared via standardized Beta (b) values (Büyüköztürk, 2017).

\section{Results}

Correlations regarding interpersonal problem inventory, defense style questionnaire imployed in present research are presented in Table 2.

Table 2

Correlations among interpersonal problem-solving inventory and defense style questionnaire

\begin{tabular}{|c|c|c|c|c|c|c|}
\hline Variables & 1 & 2 & 3 & 4 & 5 & 6 \\
\hline Negative orientation to the problem & & & & & & \\
\hline Constructive problem solving & -0.069 & - & & & & \\
\hline Lack of self-confidence & $0.375 * *$ & $-0.22 * *$ & - & & & \\
\hline Unwilling to take responsibility & $0.206^{* *}$ & -0.064 & $0.242^{* * *}$ & - & & \\
\hline Insistent-persevering orientation & $0.111 *$ & $0.454^{* * *}$ & $-0.11 *$ & -0.001 & - & \\
\hline Immature defense style & $0.404^{* *}$ & $-0.297 * *$ & $0.45^{* *}$ & 0.091 & -0.056 & \\
\hline
\end{tabular}

Table 2 displays that there is a medium level and positive relation between negative problem orientation and immature defense mechanisms $(r$ $=0.404, p<0.01)$, medium level and negative relation with constructive problem solving and immature defense mechanisms $(r=-0.297, p$ $<0.01)$, medium level and positive relation 
between lack of self-confidence and immature defense mechanisms $(r=0.45, p>0.05)$. There is no significant relationsihip unwilling to take responsibility $(r=0.091, p>0.05)$ and insistentpersevering orientation $(r=-0.56, p>0.05)$ with immature defense mechanisms.

In order to determine the predictive level of interpersonal problem-solving variables on immature defense mechanisms, multilinear regression analysis was carried out and the obtained results are in Table 3.

Table 3

Multiple regression analysis for the prediction of immature defense mechanisms

\begin{tabular}{lrlrrr}
\hline \multicolumn{1}{c}{ Variables } & \multicolumn{1}{c}{$\mathrm{B}$} & \multicolumn{1}{c}{$\mathrm{SH}_{\mathrm{B}}$} & \multicolumn{1}{c}{$\beta$} & \multicolumn{1}{c}{$T$} & \multicolumn{1}{c}{$p$} \\
\hline Negative orientation to the problem & 0.753 & 0.122 & 0.275 & 6,182 & $0^{* * *}$ \\
Constructive problem solving & -0.753 & 0.146 & -0.238 & -5.148 & $0^{* * *}$ \\
Lack of self-confidence & 2.015 & 0.291 & 0.314 & 6,936 & $0^{* * *}$ \\
Unwilling to take responsibility & -0.406 & 0.301 & -0.057 & -1.352 & 0.177 \\
Immature defense style & 0.375 & 0.307 & 0.056 & 1.224 & 0.222 \\
\hline \multicolumn{2}{c}{$R=0.561 R^{2}=0.315$} & $F_{(5.422)}=380.767$ & $p=0.001$ \\
\hline$* * * \mathrm{p}<0.001$ & & &
\end{tabular}

Table 3 shows that all variables detected as predictive variables collectively predict immature defense style on significant level $(p<0.001)$ and explain about $32 \%$ of the variance in immature defense style. As relevant Beta values are examined it surfaces that the strongest predictor of immature defense style is lack of self-confidence $(b=0.314)$ ensued by negative orientation to the problem $(b=0.275)$ and a constructive problem solving $(b=-0.238)$ variables.

\section{Discussion}

When research findings are examined, it was seen that there is a moderate positive relationship between the dimensions of negative approach to the problem and of lack of self-confidence of interpersonal problem-solving and immature defense form, and moderate negative relationship between the dimension of constructive problem solving of interpersonal problem-solving and immature defense form. It was concluded that there is no significant relationship between the dimensions of unwilling to take responsibility and of insistent-persevering approaches of interpersonal problem-solving and immature defense form. Besides, when the results of the analysis were examined to see which variables explain the use of immature defense mechanisms, it was seen that the strongest predictor variable was lack of self-confidence, which was followed by the variables of negative approach to the problem and constructive problem solving, respectively. In social problem solving model, it is important to be confident in functional solving the problems experienced. Individuals feeling inadequate themselves in terms of self-confidence show passiveness and insecurity adopting avoidant style when faced with problems. An individual in that case prefer to avoid problem rather than overcome it. $\mathrm{He} /$ she delays it as far as possible, and waits for it to be solved by itself. This increases the use of immature defense mechanisms. However, having a self-confident personality trait will increase the frequency of using mature defense mechanisms such as humor and sublimation (Weinberger, 1998). Having frequent recourse to immature defense mechanisms, depending on mutual interaction, may prevent an individual from learning effective problem solving skill (Cüceloğlu, 2018).

Another finding is that the predictor variable of using immature defense mechanisms is negative approach to the problem. In the social problem solving model, negative approach to the problem includes negative thoughts and emotions towards the problem experienced (D'Zurilla et al., 2004; Eskin, 2018). Having negative thoughts and feelings on experienced problems causes individual to approach problems negatively, which adversely affects his/her daily life adjustments (Bell \& D'Zurilla, 2009). The negative approach prevents to give meanings to experienced problems, with different point of view, produce alternative solution options, and decision making skill (Metzger, 2014). This approach limits individual to look problems from a broad perspective (Özcan \& Öğ̈ülmüş, 2010). This can lead individual to avoid from problems, and use immature defense mechanisms more than ever. As consistent with previous finding, individuals who adversely approach the problems that they face don't believe that they can solve 
these problems, and their self-sufficiency can be lower. They can exhibit the behavior of avoiding from problems, and an increase in the frequency of using immature defense mechanisms can be observed. In the study by Seaton and Beaumont (2011), it was concluded that individuals with unsociable personality trait use immature defense mechanisms more frequently. On the other hand, to regard faced problem as an opportunity, attempt to solve it, and the positive viewpoint of individual in case of being unable to solve problem are factors that help him/her to meet adverse events in a mature way (Ellis \& Harper, 2017). In spite of experienced problems, these positive thoughts and feelings help individual to use his/her psychological and social resources (Folkman, 2008).

Another finding is that the predictor variable of recourse level to immature defense mechanisms is constructive problem solving skill. As constructive problem solving skill increase, the level of use of immature defense mechanisms decreases. Using his/her problem solving ability will help someone to cope with difficulties that he/she experienced. Constructive problem solving skill is a functional problem solving approach. It includes process phases such as identifying problem, creating alternative options, decision making and application. Besides, some studies suggested that the increase in the level of social skills has an important effect on individual to feel competent himself (Erözkan, 2013), and on constructive solution of the problems encountered in interpersonal relations (Joseph \& Strain, 2010; Sumi, 2012; Türnüklü, 2017). Constructive problem solving skill is a preventative factor in coping with stress and anxiety (Korkut, 2017; Linda, Marroquín, \& Miranda, 2012). In meta analysis by Johnson and Johnson (2004), while the students participating in the problem solving skill training used win, lose, power assertion, and withdrawal strategies before training, they tended to use problemsolving- oriented process after the training.

When these three findings were evaluated together, lack of self-confidence, increase in negative approach to the problem, and decrease in constructive problem solving skill were found to be effective on adolescents' levels of use of immature defense mechanisms. The result of the study reveals the importance of problem solving skill in terms of decrease in adolescents' levels of use of immature defense mechanisms. Adolescents' intensive recourse to immature defense mechanisms can negatively affect their life adjustments, causing their psychological integrity to be damaged. This situation is within school psychological counselors' field of interest. Therefore, psychoeducation programs (interpersonal problem solving, conflict resolution, social skills training, etc.) and individual psychological counseling practice studies that will help them gain social problem solving skill are recommended in preventive guidance and psychological counseling services to be carried out with children and adolescents. The study group of the research consisted of students continuing high school in Konya, Turkey. Conducting this study with adolescents receiving formal education is one of the limitations of the study. In terms of generalizability of its findings, the study should be repeated with different groups such as adolescents outside formal education or those with different qualifications. The study findings should be supported with experimental studies.

\section{Acknowledgements}

A portion of this study has been presented in Y1ldz International Conference on Educational Research and Social Sciences in 2014.

\section{References}

Anderson, R. J., Goddard, L., \& Powell, J. H. (2011). Social problem-solving and depressive symptom vulnerability: The importance of real-life problemsolving performance. Cognitive Therapy and Research, 35, 48-56. https://doi.org/10.1007 /s10608-009-9286-2

Andrews, G., Singh, M., \& Bond, M. (1993). The Defense Style Questionnaire. The Journal of Nervous and Mental Disease, 181(4), 
246-256. https://doi.org/10.1097/00005053 $-199304000-00006$

Baltaci, Ö., \& Hamarta, E. (2013). Analyzing the relationship between social anxiety, social support and problem solving approach of university students. Education and Science, 38(167), 226-240. Retrieved from http://eb.ted.org.tr/index.php/EB/arti cle/viewFile/1757/479

Basut, E. (2006). Stress, coping and adolescence. Turkish Journal of Child and Adolescent Mental Health, 13(1), 31-36. Retrieved from http://cms.galenos.com.tr/Uploads/Ar ticle 30306/cogepderg-13-31.pdf

Bell, A. C., \& D'Zurilla, T. J. (2009). The influence of social problem-solving ability on the relationship between daily stress and adjustment. Cognitive Therapy and Research, 33, 439-448. https://doi.org/10.1007/s1060 8-009-9256-8

Bodur, E. F. (1999). Defense style questionnaire (savunma biçimleri testi) ego savunma mekanizmaları testinin Türkçe formu dil eşdeğerlilĭgi, güvenirlik ve geçerlilik çalışmast [A study on language equivalence, reliability and validity of the Turkish version of defense style questionnaire] (Yüksek lisans tezi) [(Master's Thesis)]. İstanbul Üniversitesi Sosyal Bilimler Enstitüsü, İstanbul.

Bushman, B. B., \& Peacock, G. G. (2010). Does teaching problem-solving skills matter? An evaluation of problem-solving skills training for the treatment of social and behavioral problems in children. Child $\mathcal{E}$ Family Behavior Therapy, 32, 103-124. https ://doi.org/10.1080/07317101003776449

Büyüköztürk, Ş. (2017). Sosyal bilimler için veri analizi el kitabr [Manual for data analysis in social sciences]. Ankara: Pegem Yayıncilik.

Brody, S., \& Costa, R. M. (2013). Associations of immature defense mechanisms with personal importance of junk food, television and alcohol are independent of age. Psychiatry Research, 209(3), 535-539. https://doi.org/10.1016/j.psychres .2013 .06 .035

Chávez-León, A. C., Lara-Muñoz, M. C., \& Ontiveros-Uribe, M. P. (2006).
An empirical study of defense mechanisms in panic disorder. Salud Mental, 29(6), 15-22. Retrieved from https://pdfs.semanticscholar.org/7678 /320716bcfd22fa18e5887430ea226eef052c .pdf

Cramer, P. (1998). Coping and defense mechanisms: What's the difference?. Journal of Personality, 66 (6), 919-946. https ://doi.org/10.1111/1467-6494.00037

Cramer, P. (1999). Personality, personality disorders, and defense mechanisms. Journal of Personality, 67(3), 535-554. https://doi.or $\mathrm{g} / 10.1111 / 1467-6494.00064$

Cramer, P. (2002). Defense mechanisms, behavior, and affect in young adulthood. Journal of Personality, 70(1), 103-126. https ://doi.org/10.1111/1467-6494.00180

Cüceloğlu, D. (2018). İnsan ve davranış [Man and his behavior]. İstanbul: Remzi Kitabevi.

Çam, S., \& Tümkaya, S. (2008). Kişilerarası problem çözme envanteri lise öğrencileri formu'nun geçerlik ve güvenirlik çalışması [A study on the validity and reliability of interpersonal problem solving inventory high school students form]. Uluslar Arası İnsan Bilimleri Dergisi, 5(2), 1-17. Retrieved from https://toad.halileksi.net/sites/default/ files/pdf/kisilerarasi-problem-cozme-envan teri-lise-ogrencileri-formu-toad.pdf

D'Zurilla, T. J., \& Goldfried, M. R. (1971). Problem solving and behavior modification. Journal of Abnormal Psychology, 78, 107-126. https://doi.org/10.1037/h0031360

D'Zurilla, T. J., Chang, E. C., \& Sanna, L. J. (2003). Self-esteem and social problem solving as predictors of aggression in college students. Journal of Social and Clinical Psychology, 22 (4), 424-440. https://doi.org/ 10.1521/jscp.22.4.424.22897

D'Zurilla, T. J., Maydeu-Olivares, A., \& Pujol, D. G. (2011). Predicting social problem solving using personality traits. Personality and Individual Differences, 50(2), 142-147. h ttps://doi.org/10.1016/j.paid.2010.09.015

D’Zurilla, T. J., Nezu, A. M., \& Maydeu-Olivares, A. (2004). Social problem solving: Theory and assesment. In E. Chang, T. J. D'Zurilla 
\& L. J. Sanna (Eds.), Social problem solving: Theory, research and training (pp. 11-27). Washington, DC: American Psychological Association. https://doi.org/10.1037/10805 $-000$

Davidson, K. W., MacGregor, M. V., Johnson, E. A., Woody, E. Z., \& Chaplin, W. F. (2004). The relation between defense use and adaptive behavior. Journal of Research in Personality, 38(2), 105-129. https://doi.org/ 10.1016/S0092-6566(03)00054-0

Dickinson, W. L., \& Ashby, J. S. (2005). Multidimensional perfectionism and ego defenses. Journal of College Student Psychotherapy, 19(3), 41-53. https://doi.org/ 10.1300/J035v19n03_05

Ellis, A., \& Harper, R. A. (2017). Akllcl yaşam klavuzu [A guide to rational living] (Translated by Semra Kunt Akbaş). İstanbul: Eksi Kitaplar.

Ergin, B. E., \& Dağ, İ. (2013). Kişilerarası problem çözme davranışları, yetişkinlerdeki bağlanma yönelimleri ve psikolojik belirtiler arasındaki ilişkiler [The relationship between interpersonal problem solving behaviors, adult attachment patterns and psychological symptoms]. Anatolian Journal of Psychiatry, 14, 36-45. https://doi.org/10.5 455/apd.35958

Erözkan, A. (2013). The effect of communication skills and interpersonal problem solving skills on social self-efficacy. Educational Sciences: Theory EO Practice, 13(2), 739-745. Retrieved from https://files.eric.ed.gov/fullt ext/EJ1017303.pdf

Eskin, M. (2018). Sorun çözme terapisi [Problem solving therapy]. Ankara: Altınordu Yayın.

Evren, C., Özçetinkaya, S., Çağıl, D., Ülkü, M., Can, Y., \& Mutlu, E. (2012). Defense styles that are related with history of selfmutilation and suicide attempt in alcohol dependent inpatients. Düşünen Adam The Journal of Psychiatry and Neurological Sciences, 25, 345-352. https://doi.org/10.53 50/DAJPN2012250407

Fidan, T., Ceyhun, H. E. \& Kırpınar, İ. (2009). Gençlerin kullandığı başa çıkma tutumlarının intihar girişimi ile ilişkisi [The relationship between coping attitudes of young individuals and suicide attempts]. Klinik Psikofarmokoloji Bülteni, 19(1), 214-216. Retrieved from https://search.proquest.com/openvie w/873d5b295bdfb8b152df8f05767abb43/1 $? \mathrm{cbl}=28708 \& \mathrm{\& q}$-origsite $=$ gscholar

Flett, G. L., Besser, A., \& Hewitt, P. L. (2005). Perfectionism, ego defense styles, and depression: A comparison of selfreports versus informant ratings. Journal of Personality, 73(5), 1355-1396. https://doi.or g/10.1111/j.1467-6494.2005.00352.x

Folkman, S. (2008). The case for positive emotions in the stress process. Anxiety, Stress and Coping, 21 (1), 3-14. https://doi.o $\mathrm{rg} / 10.1080 / 10615800701740457$

Freud, A. (2015). Ben ve savunma mekenizmalar [Ego and the mechanism of defense]. İstanbul: Metis Yayınları.

Geçtan, E. (2017). Psikanaliz ve sonrast [Psychoanalysis and afterwards]. İstanbul: Metis Yayınları.

Gerring, R. J., \& Zimbardo, P. G. (2016). Psikoloji ve yaşam [Psyhology and life]. Ankara: Nobel Yayın Dağıtım.

Hentschel, U., Smith, G., \& Draguns, J. G. (2004). Defense mechanisms and their psycho-physiological correlates. In U. Hentschel, G. Smith, J. G. Draguns \& Ehlers, W. (Eds.), Defense mechanisms: Theoretical, research and clinical perspectives (pp. 611-634). Amsterdam: Elsevier.

Hirsch, J. K., Chang, E. C., \& Jeglic, E. L. (2012). Social problem solving and suicidal behavior: Ethnic differences in the moderating effects of loneliness and life stress. Archives of Suicide Research, 16, 303-315. https://doi.org/10.1080/13811118 .2013 .722054

Holen, S., Lervag, A., Waaktaar, T., \& Ystgaard, M. (2012). Exploring the associations between coping patterns for everyday stressors and mental health in young schoolchildren. Journal of School Psychology, 50, 167-193. https://doi.org/10.1016/j.jsp.2 011.10 .006 
Ahmet Bedel.

Hyphantis, T., Goulia, P., \& Carvalho, A. F. (2013). Personality traits, defense mechanisms and hostility features associated with somatic symptom severity in both health and disease. Journal of Psychosomatic Research, 75, 362-369. https: //doi.org/10.1016/j.jpsychores.2013.08.014

Hyphantis, T., Palieraki, K., Voulgari, P. V., Tsifetaki, N., \& Drosos, A. A. (2011). Coping with health-stressors and defence styles associated with health-related quality of life in patients with systemic lupus erythematosus. Lupus, 20, 893-903. https:// doi.org/10.1177/0961203311398264

Johnson D. W., \& Johnson R. T. (2004). Implementing the "teaching students to be peacemakers program". Theory into Practice, 43(1), 68-79. https://doi.org/10.1207/s1543 0421tip4301_9

Joseph, G. E., \& Strain, P. S. (2010). Teaching young children interpersonal problemsolving skills. Young Exceptional Children, 13(3), 28-40. https://doi.org/10.1177/1096 250610365144

Karataş, Z. (2011). Okul pansiyonunda kalan ergenlerin kaygı düzeyleri ve problem çözme becerilerinin incelenmesi [An investigation of problem solving skills and anxiety levels of adolescents in boarding schools]. Mehmet Akif Ersoy Üniversitesi Eğitim Fakültesi Dergisi, 11(21), 208-222. Retrieved from https://dergipark.org.tr/en/ download/article-file/181321

Korkut, F. (2017). Okul temelli önleyici rehberlik ve psikolojik danışma [School-based preventive guidance and psychological counseling]. Ankara: Anı Yayıncilik.

Kulaksızoğlu, A. (2017). Ergenlik psikolojisi [Adolescent psychology]. İstanbul: Remzi Kitabevi.

Kwon, P. (2002). Hope, defense mechanisms, and adjustment: Implications for false hope and defensive hopelessness. Journal of Personality, 70 (2), 207-231. https://doi.org/ 10.1111/1467-6494.05003

Linda, W. P., Marroquín, B., \& Miranda, R. (2012). Active and passive problem solving as moderators of the relation between negative life event stress and suicidal ideation among suicide attempters and nonattempters. Archives of Suicide Research, 16, 183-197. https://doi.org/10.1080/13811118 .2012 .695233

Lyke, J. (2016). Defense style predicts subjective well-being in a non-clinical sample. The Journal of Happiness E) Well-Being, 4(1), 62-71. Retrieved from http://www.journalofhappiness.net/fr ontend/articles/pdf/v04i01/6.pdf

Malone, J. C., Cohen, S., Liu, S. R., Vaillant, G. E., \& Waldinger, R. J. (2013). Adaptive midlife defense mechanisms and late-life health. Personality and Individual Differences, 55, 85-89. https://doi.org/10.1016/j.paid.20 13.01.025

Metzger, J. A. (2014). Adaptive defense mechanisms: Function and transcendence. Journal of Climical Psychology, 70(5), 478-488. https://doi.org/10.1002/jclp.2209 1

Nezu, A. M., D'Zurilla, T., \& Nezu, C. M. (2012). Problem solving therapy: A treatment manuel. New York: Springer.

Offer, R., Lavie, R., Gothelf, D., \& Apter, A. (2000). Defense mechanisms, negative emotions, and psychopathology in adolescent inpatients. Comprehensive Psychiatry, 41 (1), 35-41. https://doi.org/10. 1016/S0010-440X(00)90129-9

Öğülmüş, S. (2006). Kişiler arası sorun çözme becerileri ve eğitimi [Interpersonal problemsolving skills training]. Ankara: Nobel Yayın Dağıtım.

Öner, N. (1977). Durumluk ve sürekli kayg envanterinin Türk toplumundaki geçerliliği [Validity of the state and trait anxiety mventory in Turkish society], (Associate Professorship Dissertation), Ankara.

Özcan, C., \& Öğülmüş, S. (2010). Dikkat eksikliği hiperaktivite bozukluğu olan çocuklara bilişsel yaklaşıma dayalı kişiler arası sorun çözme eğitiminin katkıları [Contribution of cognitive based interpersonal problem solving training to children with attention deficit hyperactivity disorder]. TAF Koruyucu Hekimlik Bülteni, 
9(4), 391-398. Retrieved from https://www .korhek.org/khb/khb_009_04-391.pdf

Özdemir, Y., Kuzucu, Y., \& Koruklu, N. (2013). Social problem solving and aggression: The role of depression. Australian Journal of Guidance and Counselling, 23(1), 72-81. htt ps://doi.org/10.1017/jgc.2013.1

Pellitteri, J. (2002). The relationship between emotional intelligence and ego defense mechanisms. The Journal of Psychology, 136(2), 182-194. https://doi.org/10.1080/0 0223980209604149

Perry, J. C., \& Metzger, J. (2014). Introduction to "Defense Mechanisms in Psychotherapy". Journal of Clinical Psychology, 70(5), 405. ht tps://doi.org/10.1002/jclp.22084

Presniak, M. D., Olson, T. R., \& Macgregor, M. W. M. (2010). The role of defense mechanisms in borderline and antisocial personalities. Journal of Personality Assessment, 92 (2), 137-145. http s://doi.org/10.1080/00223890903510373

Santrock, J. W. (2014). Ergenlik [Adolescence], (Translation editor. Diğdem Müge Siyez). Ankara: Nobel Yayın Dağıtım.

Savaşır, I., \& Şahin, N.H. (1997). Bilişseldavranışç terapilerde değerlendirme: Slk kullanilan ölçekler [Evaluation in cognitivebehavioral therapies: Frequently used scales]. Ankara: Türk Psikologlar Derneği Yayınları.

Seaton, C. L., \& Beaumont, S. L. (2011). Identity processing styles and defense styles during emerging adulthood: Implications for life distress. Identity: An International Journal of Theory and Research, 11, 1-24. https://doi.o $\mathrm{rg} / 10.1080 / 15283488.2011 .540736$

Seçer, Z., \& Ogelman, H. G. (2011). Analysis of the effect of a social problemsolving program on the aggression of children. Australian Journal of Guidance and Counselling, 21 (2), 142-153. https://doi.org /10.1375/ajgc.21.2.142

Siu, A. M. H., \& Shek, D. T. L. (2010). Social problem solving as a predictor of well-being in adolescents and young adults. Social Indicators Research, 95, 393-406. https://doi .org/10.1007/s11205-009-9527-5
Spirito, A., Francis, G., Overholser, J., \& Frank, N. (1996). Coping, depression and adolescent suicide attempts. Journal of Clinical Psychology, 25(2), 147-155. https:// doi.org/10.1207/s15374424jccp2502_3

Steiner, H., Erickson, S. J., MacLean, P., Medic, S., Plattner, B., \& Koopman, C. (2007). Relationship between defenses, personality, and affect during a stress task in normal adolescents. Child Psychiatry and Human Development, 38, 107-119. https://doi.org/1 0.1007/s10578-007-0046-9

Sumi, K. (2012). Relationship of social problem-solving ability with interpersonal relationships: A prospective study among Japanese women and men. Psychological Reports: Relationships $\mathcal{E}$ Communications, 111 (3), 929-937. https://doi.org/10.2466/2 1.20.28.PR0.111.6.929-937

Tabachnik, B. G., \& Fidel, L. S. (2015). Çok değişkenli istatistiklerin kullanım [Using multivariate statistics)] (Translation ed. Mustafa Baloğlu). Ankara: Nobel Yayıncilik.

Türnüklü, A. (2017). Sinıf yönetimi [Classroom management]. In E. Karip (Ed.), Öğrenciler arasindaki çatışmaların çözümünde problem çözme ve arabuluculuk [Problem solving and mediation in resolving conflicts between students]. Ankara: Pegem Yayıncilik. https:/ /doi.org/10.14527/9786054282609.08

Waqas, A., Rehman, A., Malik, A., Muhammad, U., Khan, S., \& Mahmood, N. (2015). Association of ego defense mechanisms with academic performance, anxiety and depression in medical students: A mixed methods study. Cureus, 7(9). https://doi.org /10.7759/cureus.337

Weinberger, D. A. (1998). Defenses, personality structure, and development: Integrating psychodynamic theory into a typological approach to personality. Journal of Personality, 66(6), 1061-1080. https://doi.or $\mathrm{g} / 10.1111 / 1467-6494.00042$

Yenice, N. (2012). Öğretmen adaylarının özyeterlik düzeyleri ile problem çözme becerilerinin incelenmesi [Investigating the self-efficacy and problem solving 
Ahmet Bedel.

skills of preservice teachers]. Elektronik Sosyal Bilimler Dergisi, 11(39), 36-58. https://dergipark.org.tr/tr/pub/esosd er/issue/6153/82657

Yilmaz, N., Gençöz, T., \& Ak, M. (2007). Savunma biçimleri testi'nin psikometrik özellikleri: Güvenilirlik ve geçerlik çalışması [A study on reliability and validity of psychometric properties of the Defense Style Questionnaire]. Türk Psikiyatri Dergisi, 18(3), 244-253. Retrieved from http://www.turkpsikiyatri.com/default .aspx? modul = turkceOzet\&gFPrkMakale $=589$

\section{Notes}

* Research article. 